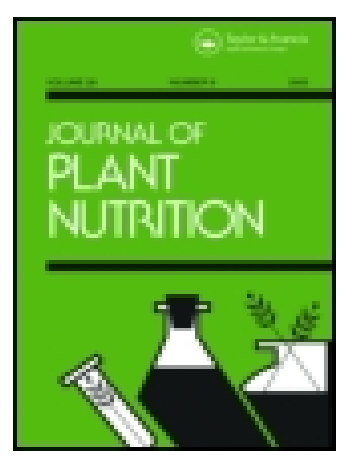

Journal of Plant Nutrition

\title{
Effects of Salinity, Drought, and Priming Treatments on Seed Germination and Growth Parameters of Lathyrus sativa L.
}

\section{Somayeh Gheidary, Davoud Akhzari \& Mohammad Pessarakli}

To cite this article: Somayeh Gheidary, Davoud Akhzari \& Mohammad Pessarakli (2017): Effects of Salinity, Drought, and Priming Treatments on Seed Germination and Growth Parameters of Lathyrus sativa L., Journal of Plant Nutrition, DOI: 10.1080/01904167.2016.1269349

To link to this article: http://dx.doi.org/10.1080/01904167.2016.1269349

Accepted author version posted online: 25

Jan 2017.

Submit your article to this journal $\sqsubset$

a

View related articles 두

View Crossmark data $₫$ 


\section{ACCEPTED MANUSCRIPT}

Effects of Salinity, Drought, and Priming Treatments on Seed Germination and Growth Parameters of Lathyrus sativa L.

Somayeh Gheidary, ${ }^{1}$ Davoud Akhzari ${ }^{2}$ and Mohammad Pessarakli ${ }^{3}$

${ }^{1}$ M.Sc. Graduate Student of Rangeland Management, Malayer University, Iran

${ }^{2}$ Assistant Professor, Department of Watershed and Rangeland Management, Malayer

University, Iran

${ }^{3}$ Professor, School of Plant Sciences, The University of Arizona, Tucson, Arizona 85721, USA

Address Correspondence to Mohammad Pessarakli: pessarak@email.arizona.edu 


\section{ACCEPTED MANUSCRIPT}

\section{ABSTRACT}

Germination of plants is one of the most important stages during their growth which is often influenced by environmental stresses, especially drought and salinity. This study was conducted to investigate the effects of salinity and drought on seed germination and growth of Lathyrus sativa. The experiment was laid out in a completely randomized design with factorial arrangement in 4 replications. Salinity treatments were 0,2 , and $4 \mathrm{dS} / \mathrm{m}$ and drought treatments included $0,0.4,0.8,1.2 \mathrm{MPa}$. Salinity and drought treatments were prepared by using sodium chloride and polyethylene glycol 6000, respectively. The results showed that salinity and drought stresses decreased germination percentage, root and radicle length.

Keywords: Salinity stress, drought stress, seed priming, radicle length, stem length 


\section{ACCEPTED MANUSCRIPT}

\section{INTRODUCTION}

The emergence and development of the necessary structures (depending on the type of seed) is called embryo germination (AOSA, 2000). Plant species, after planting, are faced with physical stresses such as high temperature, increasing or decreasing water, salinity, soil crusting. They also face biological stresses such as diseases, pests and weeds. Their seedling production will be faced with problems, and percentage of germination will be reduced and in difficult conditions these factors may even prevent germination, while the germination of plant species has significant impacts on their ability to establish (Arin and Kiyak, 2003). In many rangeland plants, seed germination and initial seedling growth are the most sensitive stages of their growth and development to environmental stresses (Kaya et al., 2006). In addition, uniformity of germination, the average time of germination and emergence are also important factors for seed quality (Soltani et al., 2006). Seed germination begins with water absorption and is followed by sequential biochemical events in the seed (Greipsson, 2001) which includes metabolism activities, digestion of the storage material and transmission to the fetus, cell division and growth (Albeles and Lonsilk, 1996). This phase of plant life has a determining role in the proper settlement of the plant and its final performance (Almansouri

et al., 2001). Thus, there are strategies to increase germination of the plant species against environmental stresses, among which seed priming has a significant importance (Fujikura, 1993). Based on definition, priming consists of a number of different methods to improve seed germination and the controlled irrigation of seed is applied in all of them (Basra et al., 2003; Farooq et al., 2006) which leads to metabolic activities before germination, but prevents departure of the radicle (Bradford, 1986; Nascimento and Aragão, 2004). Finally, 


\section{ACCEPTED MANUSCRIPT}

before its emergence, the seed radicle is re-dried (it is returned to initial moisture content), then the seeds are saved or planted (Corbineau and Come, 2006; McDonald, 2000). During this phase of the storage of the material transmission, activation and synthesis of several enzymes, ribonucleic acid (RNA) synthesis, deoxyribonucleic acid (DNA) synthesis and cytoplasmic membrane improvement occur in the seed (Hosseini and Kochaki, 2007).

The amount or severity of adverse environmental factors which directly or indirectly damage plants plus limitations in the development of critical processes in plants are called environmental stresses (Fowden et al., 1993). Stress is considered the conditions in which plants are far away from the optimum growing conditions and this may be irreversible. Plants have different reactions against environmental stresses (Tabaie Aghdaie, 1996) and use a variety of defense mechanisms (Horváth et al., 2007) to reduce their adverse effects. These operations are called stress tolerance mechanisms (Ebrahimzadeh, 1990). The shortage of the required plant water and also its poor quality as a result of drought and salinity stresses are the most important instances of environmental stresses in rangeland plants which prevent their normal growth and reduce their performance (Khan and Gulzar, 2003). In many parts of the world, plants' activity and growth are limited by various biotic and abiotic environmental stresses. Among abiotic stresses, salinity has caused extensive damages to plants around the world (MirMohammadi Maybodi and Ghareh Yazy, 2002). In addition to its toxicity to plants, salinity causes drought stress in them (Akhzari and Aghbash, 2013). Drought also is one of the most important factors reducing soil and water potential and disrupts different stages of plant growth and development, especially germination in arid and semi-arid regions. Once it occurs in plants, the amount of water a plant receives becomes less than the amount it

\section{ACCEPTED MANUSCRIPT 4}




\section{ACCEPTED MANUSCRIPT}

losses which may be due to excessive water loss or absorption or both (Akhzari and Aghbash, 2013). In addition, some conditions are created in which Turzsans are not completed in plant cells and tissues (Zareh Chahouki, 2000). In many plants, polyethylene glycol (PEG) is used to cause drought stress. Since PEG is not absorbed by the plants, its concentration remains fixed in the whole duration of the stress and that is why it is known as the best treatment for osmotic stress compared to other osmolytes such as mannitol, sugar, and salt (Kramer and Boyer, 1995; Dami and Haghes, 1997).

Lathyrus sativa grows in Iranian rangelands, which can be introduced in the saline and arid rangelands. The objective of this research was to study the effects of salinity, drought, and priming treatments on seed germination and growth parameters of Lathyrus sativa $\mathrm{L}$.

\section{MATERIALS AND METHODS}

In this study, first of all, the seed pods were removed and 100 of the seeds were put into petri dishes with filter paper in 4 replicates and these containers were moistened with distilled water and the samples were taken into the Germinator with variable $30-20{ }^{\circ} \mathrm{C}$ temperature. After 72 hours by counting the number of germinated seeds (viability), the percentage of seed germination was determined. For germination criterion, radicles of at least $2 \mathrm{~mm}$ or more were considered. Then, the viability percentage was determined by inserting the obtained data into Equation 1. 
$\mathrm{Gp}=\frac{{ }^{\mathrm{G}}}{N} \times 100 \quad$ (Equation 1$)$

GP: percentage of seeding

G: the number of germinated seeds

$\mathrm{N}$ : the total number of seeds

This study was conducted to investigate the effects of priming on seed germination in a completely randomized design and a factorial experiment in 4 replications. In this study, three levels for seed priming were considered including:

T1: control (without priming treatment)

T2: placing the seeds in distilled water for 36 hours (hydropriming treatment)

T3: placing the seeds in soluble urea for 96 hours (osmopriming treatment)

Then, 3 levels of salinity, including electrical conductivity (EC) of 0,2 , and $4 \mathrm{dS} / \mathrm{m}$ as $\mathrm{S} 1$, $\mathrm{S} 2$, and S3, respectively and 4 levels of drought, including $0,0.4,0.8$, and $1.2 \mathrm{MPa}$ as $\mathrm{A} 1$, A2, A3, and A4, respectively were applied to the seeds and afterwards different levels of salinity and drought treatments were done in 4 replications. Sodium chloride $(\mathrm{NaCl})$ was used to apply salinity treatment. By adding $0.64 \mathrm{~g} \mathrm{NaCl}$ per $\mathrm{kg}$ soil, the $\mathrm{EC}(\mathrm{dS} / \mathrm{m})$ of soil increases by one degree (Pessarakli et al., 2006), thus the salinity levels of 2 and $4 \mathrm{dS} / \mathrm{m}$ were applied to each petri dish. To do this, $\mathrm{NaCl}(0.64 \times 2)$ and $\mathrm{NaCl}(0.64 \times 4) \mathrm{g}$ were dissolved in water and were added to each petri dish. The PEG 6000 soluble was used at four levels (0, 0.4, 0.8, and 1.2 $\mathrm{MPa}$ ) as different levels of drought treatment. Then, $314 \mathrm{~g}$ PEG per liter 


\section{ACCEPTED MANUSCRIPT}

water was used to provide the potential of $0.4,0.8,1.2 \mathrm{MPa}$ at $20^{\circ} \mathrm{C}$ (Kazemi and Eskandari, 2012).

Control level (T1) consisted of 36 petri dishes on which no salinity and drought had been applied.

(T2) level included 36 petri dishes (hydropriming treatment) to which distilled water was added for 36 hours as pre-treatment. Then, different levels of salinity and drought were applied to them.

(T3) level contained 36 petri dishes (osmopriming treatment) to which the dissolved urea was added for 96 hours as pre-treatment. Then, different levels of salinity and drought were applied to them. 4 days after applying different levels of salinity and drought, root and stem lengths were measured by a ruler and a magnifying glass.

This study was set up in a completely randomized design with factorial arrangement with 4 replications. Analysis of variance (ANOVA) was used for statistical analysis of the data. Statistical significance was defined at $\mathrm{P}<0.05$.

\section{RESULTS}

Interactive Effects of Salinity and Drought on Lathyrus Radicle Growth in Control Treatment 


\section{ACCEPTED MANUSCRIPT}

The highest radicle lengths were $169 \mathrm{~mm}$ (S1A1), $136 \mathrm{~mm}$ (S2A1), $95 \mathrm{~mm}$ (S3A1), $13.3 \mathrm{~mm}$ (S1A2) and $2.6 \mathrm{~mm}$ (S2A2), and these amounts had a descending trend to various levels of drought stress (PEG stress) (Figure 1).

\section{Interactive Effects of Salinity and Drought on Lathyrus Radicle Growth in Hydropriming Treatment}

The maximum radicle lengths were: $151.67 \mathrm{~mm}$ (S1A1), $113 \mathrm{~mm}$ (S2A1), $83.34 \mathrm{~mm}$ (S3A1), $70 \mathrm{~mm}$ (S1A2), $66.67 \mathrm{~mm}$ (S2A2), $55 \mathrm{~mm}$ (S3A2), $45 \mathrm{~mm}$ (S2A3), $28.34 \mathrm{~mm}$ (S1A3), 25 mm (S1A4) and $21.67 \mathrm{~mm}$ (S3A3), respectively. The root length also decreased by increasing salinity and drought stresses and the highest reduction in root growth was observed in the higher levels of the drought treatments. A greater increase in the root length was observed compared to the control level (Figure 2).

\section{Interactive Effects of Salinity and Drought on Lathyrus Radicle Growth in Osmopriming Treatment}

The maximum root lengths were $50 \mathrm{~mm}$ (S1A1), $18.33 \mathrm{~mm}$ (S1A2), $15 \mathrm{~mm}$ (S2A1) and 5 $\mathrm{mm}$ (S3A1), respectively. The radicle length in this treatment also decreased by increasing salinity and drought and the negative effects of PEG on root length were greater than those of sodium chloride solution (Figure 3). 


\section{ACCEPTED MANUSCRIPT}

The Interactive Effects of Salinity and Drought on Lathyrus Stem Growth in Control Treatment

The maximum stem lengths were $103.33 \mathrm{~mm}$ (S1A1), $86.67 \mathrm{~mm}$ (S2A1) and $65 \mathrm{~mm}$ (S3A1), respectively. Like radicle, stem growth decreased under salinity and drought stresses. The stem growth was affected mostly by the drought in a manner that the growth was zero in the potential of 8 and 12 times of polyethylene glycol which shows that the effects of sodium chloride stress were less than those of polyethylene glycol (Figure 4).

The Interactive Effects of Salinity and Drought on Lathyrus Stem Growth in Hydropriming Treatment

The maximum stem lengths were: $133.34 \mathrm{~mm}$ (S1A1), $111.67 \mathrm{~mm}$ (S2A1), $81.67 \mathrm{~mm}$ (S3A1), $53.34 \mathrm{~mm}$ (S1A2), $14 \mathrm{~mm}$ (S2A2), $10 \mathrm{~mm}$ (S3A2), $5 \mathrm{~mm}$ (S1A3 and S2A3) and $1.67 \mathrm{~mm}$ (S3A3), respectively. Seed priming with distilled water caused the highest radicle growth and hydropriming was the best and most effective treatment (Figure 5).

The Interactive Effect of Salinity and Drought on Lathyrus Stem Growth in Osmopriming Treatment 


\section{ACCEPTED MANUSCRIPT}

The maximum stem lengths were: $36.67 \mathrm{~mm}$ (S1A1), $15 \mathrm{~mm}$ (S2A1), $11.67 \mathrm{~mm}$ (S1A2) and $3.34 \mathrm{~mm}$ (S3A1), respectively. The descending trend of radicle growth with increasing levels of salinity and drought was also observed in this treatment (Figure. 6).

\section{DISCUSSION}

The results of this study showed that drought and salinity stresses have significant inhibitory effects on root and stem lengths. In terms of drought stress, water absorption by roots is impaired and this may reduce seed germination. It seems that the reduction in water absorption by the seeds as the result of drought stress limits their physiological and metabolic processes which are necessary for seedling survival (De and Kar, 1994). Salinity can also affect different stages of plant life such as germination, length of root and stem because as salinity increases water absorption by the seed is decreased which shows the inhibitory effect of salinity on seed germination.

Increasing germination ability, growth speed, and deployment of seedling are the factors that increase production in the rangelands. Therefore, it is important to know the effects of various chemicals on the germination of plants. The first stage of seed germination is water absorption and seed inflammation, and the last stage is cell division and cell enlargement which lead to the seed's emergence of radicle and stem.

In the present study, hydropriming had the highest emergence percentage among different seed priming treatments. The superiority of hydropriming as a treatment in increasing plant germination percentage compared to other treatments may be due to the effect of the 


\section{ACCEPTED MANUSCRIPT}

absorption of more water by seeds compared to other treatments they reached the highest percentage of germination as was reported by Kaya et al. (2006) and by Neamatollahi et al. (2009).

Cell division would be reduced and seedling growth would be incomplete if the absorption of available water around the seed is reduced due to increasing the osmotic potential. Since the radicle comes out of the seed hulls before the stem, the process of growth and development in radicle begins earlier than that of stem in case of water shortage (Mudaris and Jutzi, 1999). Khajeh Hosseini et al. (2003) found that soybean germination in sodium chloride solution is higher than that in polyethylene glycol 6000 , and the reason for this issue was faster absorption of water by the seed to achieve the necessary moisture for germination in sodium chloride solution. It is possible that seeds absorb sodium and chloride ions in the salt solution and keep their own cell osmotic potential lower than that of the solution and as a result water absorption continues in the negative potential.

Our results indicate that germination percentage and speed, radicle length and stem length were reduced by increasing the drought stress caused by polyethylene glycol. Similar results have been reported by Boroumand RezaZadeh and Kochaki (2005). In agreement with the present study, the results of an investigation conducted by Ghani et al. (2009) on yarrow herb showed that the rate and the percentage of germination and root length in all kinds of yarrow species decreased by increasing drought stress. Also, Farzaneh et al. (2009) investigating basil herb stated that wet weight, dry weight, and plant height are reduced by increasing drought stress. 


\section{ACCEPTED MANUSCRIPT}

Under drought stress, germination, root and stem lengths were significantly decreased. This is in agreement with the findings of Fateh and Alimohamadi (2010) who investigated the thyme herb and found that the percentage and speed of germination, vigor, root and stem lengths decreased by increasing drought stress. Hosseini and Rezvani Moghaddam (2006) also found that fleawort stem growth has more sensitivity to drought stress compared to other measured traits in laboratory conditions.

Based on the results of present study, applying hydropriming on seeds increased radicle length and stem growth of Lathyrus sativa. Similar results were reported by Kaur et al. (2002) who found applying hydropriming on seeds increases radicle length and stem growth of pea plant. Kang et al. (1996) also observed the increase of germination percentage and fast and steady germination of tomato in drought and salinity stress conditions. Also, Cano et al. (1991) observed the increase of tomato production in salinity stress condition. Emmerich and Hardegree (1990) studied the effect of salinity on the germination of four species of grass and observed that primed seeds had a higher germination percentage than the control seeds in salinity condition.

In general, plants with more resistance and growth in roots and radicles at this stage will also show more resistance to drought and salinity at seedling stage and other stages. It should be mentioned that the species which are resistant to drought and salinity in arid and semi-arid regions can be introduced to rangelands by using such research and use them to develop drought- and salinity-resistant vegetation in rangelands. 


\section{ACCEPTED MANUSCRIPT}

\section{REFERENCES}

Akhzari, D. and F.G. Aghbash. 2013. Effect of Salinity and Drought Stress on the Seedling Growth and Physiological Traits of Vetiver Grass (Vetiveria zizanioides Stapf.). ECOPERSIA, 1 (4): 339-352.

Albeles, F.B. and J. Lonsilk. 1996. Stimulation of lettuce seed germination by ethylene. Plant Physiology, 44: 277 -280.

Almansouri, M., J.M. Kinet, and S. Lutts. 2001. Effect of salt and osmotic stress on germination in durum wheat (Triticum aestivum Desf.). Plant and Soil, 231: 243-254.

Arin, L.E. and D.Y. Kiyak. 2003. The effect of pre_sowing treatments on emergnce and seedling growth of tomato seed (Liycopersicon esculentum Mill.) under several stress conditions. Pakistan Journal of Biological Science, 6(11):990-994.

Basra, S. M. A., I. A. Pannu, and I. Afzal. 2003. Evaluation of seed vigor of hydro and matriprimed wheat (Triticum aestivum L.) seeds. International Journal of Agriculture and Biology, 5: 121-123.

Boroumand RezaZadeh, Z., and AS. Kochaki. 2005. The reviews of ajowan and dill seed reaction to the osmotic and matric potential due to sodium chloride and polyethylene glycol 6000 in different temperatures. Iran Agricultural Research, 3 (2): 217-207.

Bradford, K. J. 1986. Manipulation of seed water relations via osmotic priming to improve germination under stress conditions. Horticultural Science, 21:1105-1112.

Cano, E.A., M.C. Bolarin, F. Perez-Alfocea, and M. Caro. 1991. Effect of NaCl priming on increased salt tolerance in tomato. Journal of Horticultural Science, 66(5): 621-628.

Corbineau, F., and D. Come. 2006. Priming: a Technique for Improving Seed Quality. Seed 


\section{ACCEPTED MANUSCRIPT}

Testing International, 132: 38-40.

Dami, I., and G. H. Haghes. 1997. Effect of PEG induced water stress on in vitro hardening of "Valiant" gape. Plant Cell, Tissue and Organ Culture, 47: 97-101.

De, F., and R. K. Kar. 1994. Seed germination and seedling growth of mung bean (Vigna radiate) under water stress included by PEG-6000. Seed Science and Technology, 23, 301-304.

Ebrahimzadeh, H. 1990. Plant physiology, Volume 1, Tehran University Press. 314 p.

Emmerich, W.E., and S.P. Hardegree. 1990. Polyethylene glycol solution contact effects on seed germination. Agronomy Journal, 82: 1103-1107.

Farooq, M., S. M. A Basra, and H.U Rehman. 2006. Seed priming enances emergence, yield, and quality of direct-seeded rice. Crop Management and Physiology, IRRN31. 2: 42-44.

Farzaneh, A., AS. Ghani, M. Azizi, and M. T. Ebadi. 2009. The effect of different levels of water stress on morphological characteristics, yield and essential oil content of basil modified varieties Keshkeni Luvelou. Proceedings of the Sixth Congress of Horticultural Sciences, University of Guilan, Rasht, 25-22 Jul: 1116-1114.

Fateh, A.V., and R. Alimohamadi. 2010. Evaluation of drought and salinity on the germination of the herb thyme (Thymus vulgaris L.). Proceedings of the Second Conference on Sustainable Agriculture and Rural Development (opportunities and challenges), Shiraz March, 12-11: 7.

Fowden, L., T. Mansfield, and J. Stoddart. 1993. Plant Adaptation to Environmental Stress. Chapman and Hall, London, 88 p.

Fujikura, M. 1993. Osmotic priming of tomato seed: Effect on germination, field emergence, 


\section{ACCEPTED MANUSCRIPT}

seedling growth and fruit yield. American Society for Horticultural Science, 112: 427432.

Ghani, A., M. Azizi, and A. Tehranifar. 2009. Response of Achillea species to drought stress induce by polyethylene glycol in germination stage. Iranian Journal of Medicinal and Aromatic Plants, 25(2): 261-271.

Greipsson, S. 2001. Effects of stratification and GA3 on seed germination of a sand stabilising grass Leymus arenarius used in reclamation. Seed Science and Technology, 29: 1-10.

Horváth, E., G. Szalai, and T. Janda. 2007. Induction of abiotic stress tolerance by salicylic acid signaling. Plant Growth Regulation, 26: 290-300.

Hosseini, A., and H. Kochaki. 2007. Priming effects of different treatments on seed germination rate and percentage of four pasture of sugar beet seed. Iranian Journal of Agricultural Research, 5 (1): 69-76.

Hosseini, H., and C. Rezvani Moghaddam. 2006. Effect of salinity and drought stress on the germination of Psyllium (Plantago ovate). Journal of Agricultural Research, 4(1): 21-15.

Kang, J.S., J.L. Cho, and Y.O. Jeong. 1996. Effect of seed priming on the germinability of tomato seeds under saline stress. Journal of the Korean Society for Horticultural Science, 37(4):516-521.

Kaur, S., A. K. Gupta, and N. Kaur. 2002. Effect of osmo- and hydropriming of chickpea seeds on seedling growth and carbohydrate metabolism under water deficit stress. Plant Growth Regulation, 37: 17-22.

Kaya, M., G. Occult, M. Atak, Y. Cikili, and O. Kolsarci. 2006. Seed treatment to overcome salt and drought stress during germination in sunflower (Helianthus annuus L.). European 


\section{ACCEPTED MANUSCRIPT}

Journal of Science, 24:291-295.

Kazemi, K., and H. Eskandari. 2012. Does priming improve seed performance under salt and drought stress? Journal of Basic and Applied Scientific Research, 2(4): 3503-3507.

Khajeh Hosseini, M., A.A. Powell and I.J. Bingham. 2003. The interaction between salinity stress and seed vigour during germination of soybean seeds. Seed Science and Technology, 31: 715-725.

Khan, M.A., and S. Gulzar. 2003. Germination responses of Sporobolu sioclados: A saline desert grass. Journal of Arid Environment, 55: 453-464.

Kramer, P. J., and J. S. Boyer. 1995. Water relation of plant and soil. Academic press. San Diego, USA, pp: 1-495.

McDonald, M.B. 2000. Seed priming. In: Black, M., Bewley, J.D. (Eds.), Seed Technology and Its Biological Basis. Sheffield Academic Press, Sheffield, UK, pp: 287-325.

MirMohammadi Maybodi, S.A. and V.B. Ghareh Yazy. 2002. Physiological aspects of plant breeding salinity. Publications of Isfahan University of Technology, $180 \mathrm{p}$.

Mudaris, A., and S.C. Jutzi. 1999. The influence of fertilizer-based seed priming treatments on emergence and seedling growth of Sorghoum bicolor and Pennisetum glaucum in put trials under greenhouse conditions. Journal of Agronomy and Crop Science, 182: 135141.

Nascimento, W.M. and F.A.S. Aragão. 2004. Muskmelon seed priming in relation to seed vigor. Scientia Agricola, 61(1):114-117.

Neamatollahi, E., M. Bannayan, A. Ghanbari, M. Haydari, and A. Ahmadian. 2009. Does hydro and osmopriming improve fennel (Foeniculum vulgare) seeds germination and seedlings 


\section{ACCEPTED MANUSCRIPT}

growth? Notulae Botanicae Horti Agrobotanici Cluj-Napoca, 37(2): 190-194.

Pessarakli, M., K.B. Marcum, and D.M. Kopec. 2006. Growth responses of desert saltgrass under salt stress. A part of the University of Arizona College of Agriculture, Turfgrass and Ornamental Research Report, 212p.

Soltani, A., M. Ghalipoor, and E. Zeinali. 2006. Seed reserve utilization and seedling of wheat as affected by drought and salinity. Journal of Environmental and Experimental Botany, 55: 195-200.

Tabaie Aghdaie, S. R. 1996. Study of environmental stresses resistance of range grasses, Pajouhesh and Sazandegi, (40, 41, 42): 41-45.

The Association of Official Seed Analysts (AOSA). 2000. Handbook of seed analysis. The University of Arizona Publication, 148p.

Zareh Chahouki, M. A. 2000. Drought stress in plants. NSC seminar of range management, Tehran University, $340 \mathrm{p}$. 


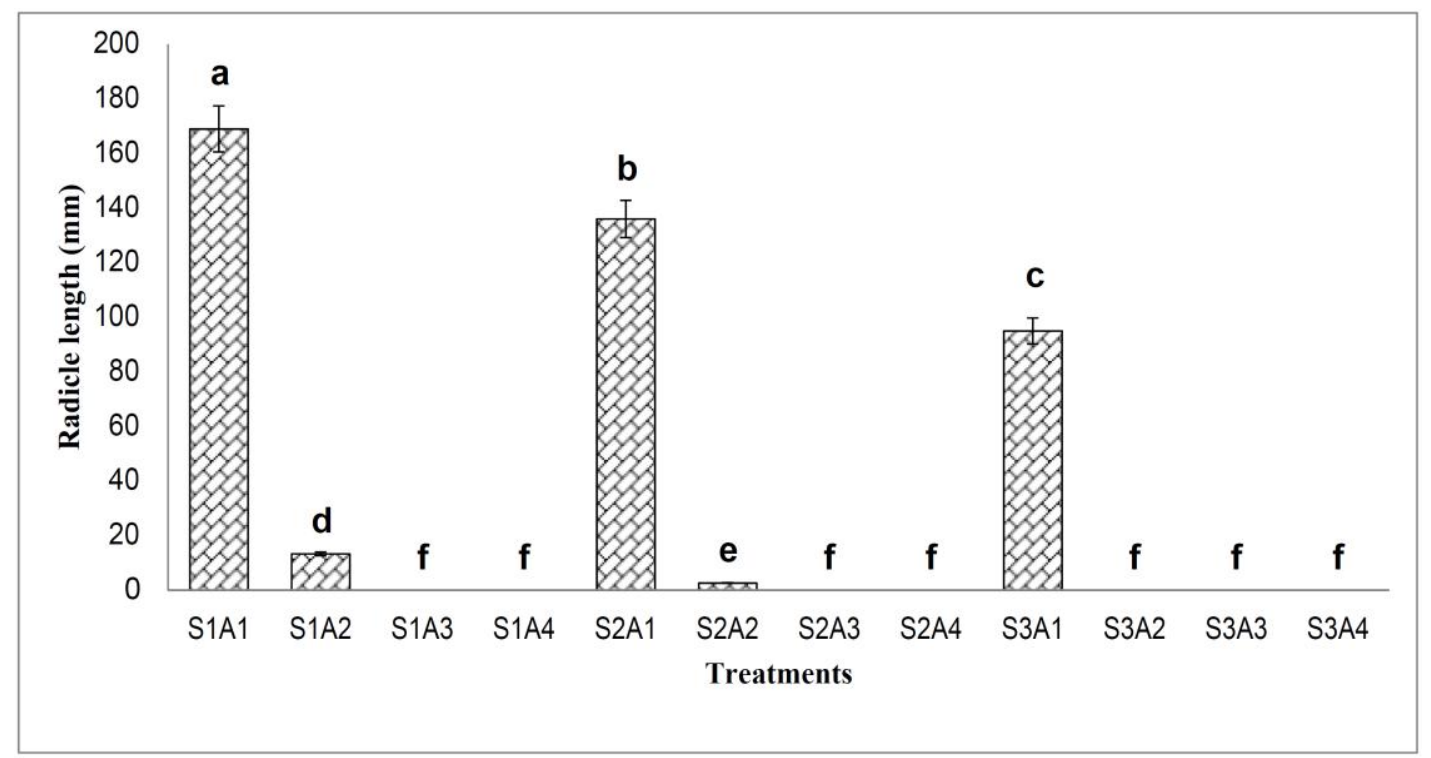

FIGURE 1. The interactive effects of salinity and drought on Lathyrus radicle growth in control treatment. Different letters on the bar graphs represent a significant difference $(\mathrm{P}<0.05)$ between plant radicle growth in different treatments $(\mathrm{S} 1, \mathrm{~S} 2$, and $\mathrm{S} 3$ represent EC of 0,2 , and $4 \mathrm{dS} / \mathrm{m}$, respectively, and $\mathrm{A} 1, \mathrm{~A} 2, \mathrm{~A} 3$, and $\mathrm{A} 4$ represent $0,0.4,0.8$, and $1.2 \mathrm{MPa}$ drought stress, respectively). 


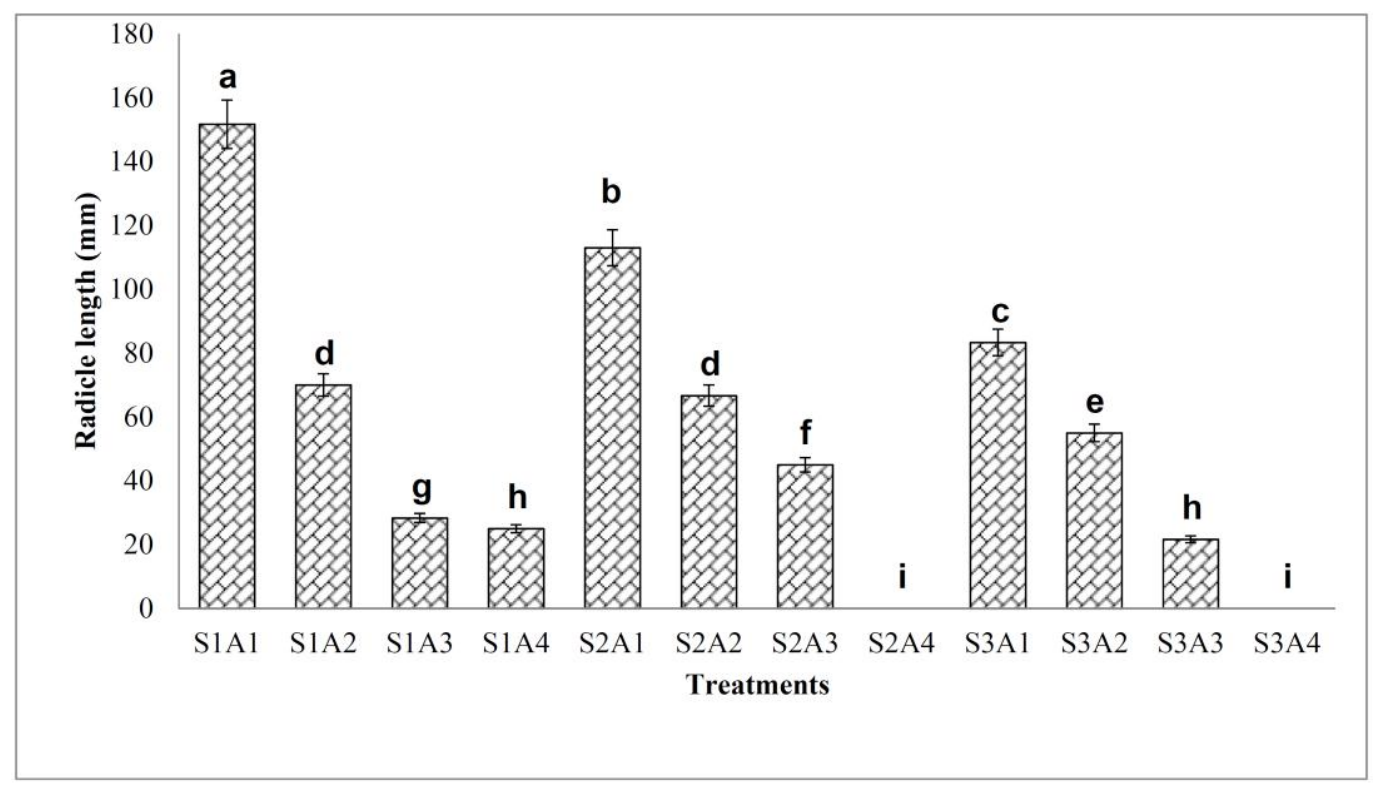

FIGURE 2. The interactive effects of salinity and drought on Lathyrus radicle growth in hydropriming treatment. Different letters on the bar graphs represent a significant difference $(\mathrm{P}<0.05)$ between plant radicle growth in different treatments $(\mathrm{S} 1, \mathrm{~S} 2$, and S3 represent EC of 0, 2, and $4 \mathrm{dS} / \mathrm{m}$, respectively, and A1, A2, A3, and A4 represent 0, 0.4, 0.8, $1.2 \quad \mathrm{MPa} \quad$ drought $\quad$ stress, respectively). 


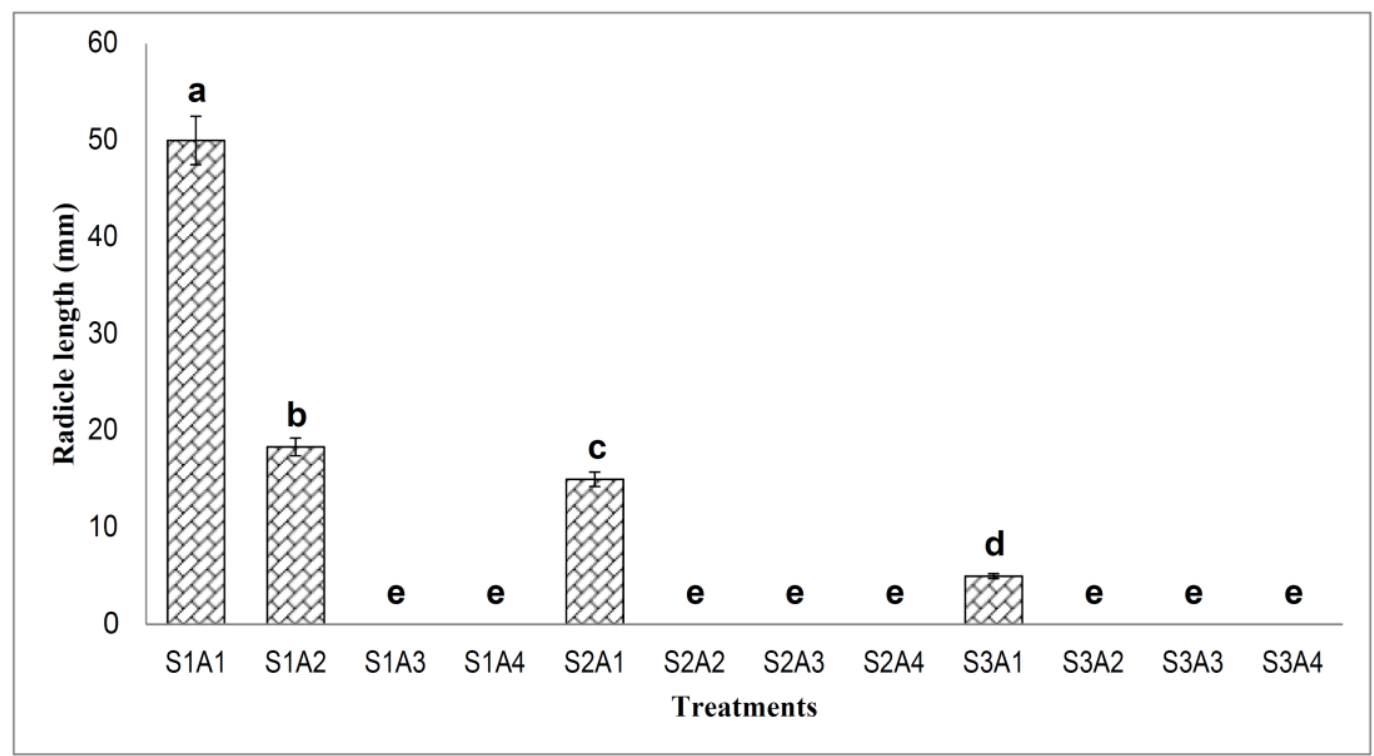

FIGURE 3. The interactive effects of salinity and drought on Lathyrus radicle growth in osmopriming treatment. Different letters on the bar graphs represent a significant difference $(\mathrm{P}<0.05)$ between plant radicle growth in different treatments $(\mathrm{S} 1, \mathrm{~S} 2$, and S3 represent EC of 0, 2, and $4 \mathrm{dS} / \mathrm{m}$, respectively, and A1, A2, A3, and A4 represent 0, 0.4, 0.8, $1.2 \quad \mathrm{MPa} \quad$ drought $\quad$ stress, respectively). 


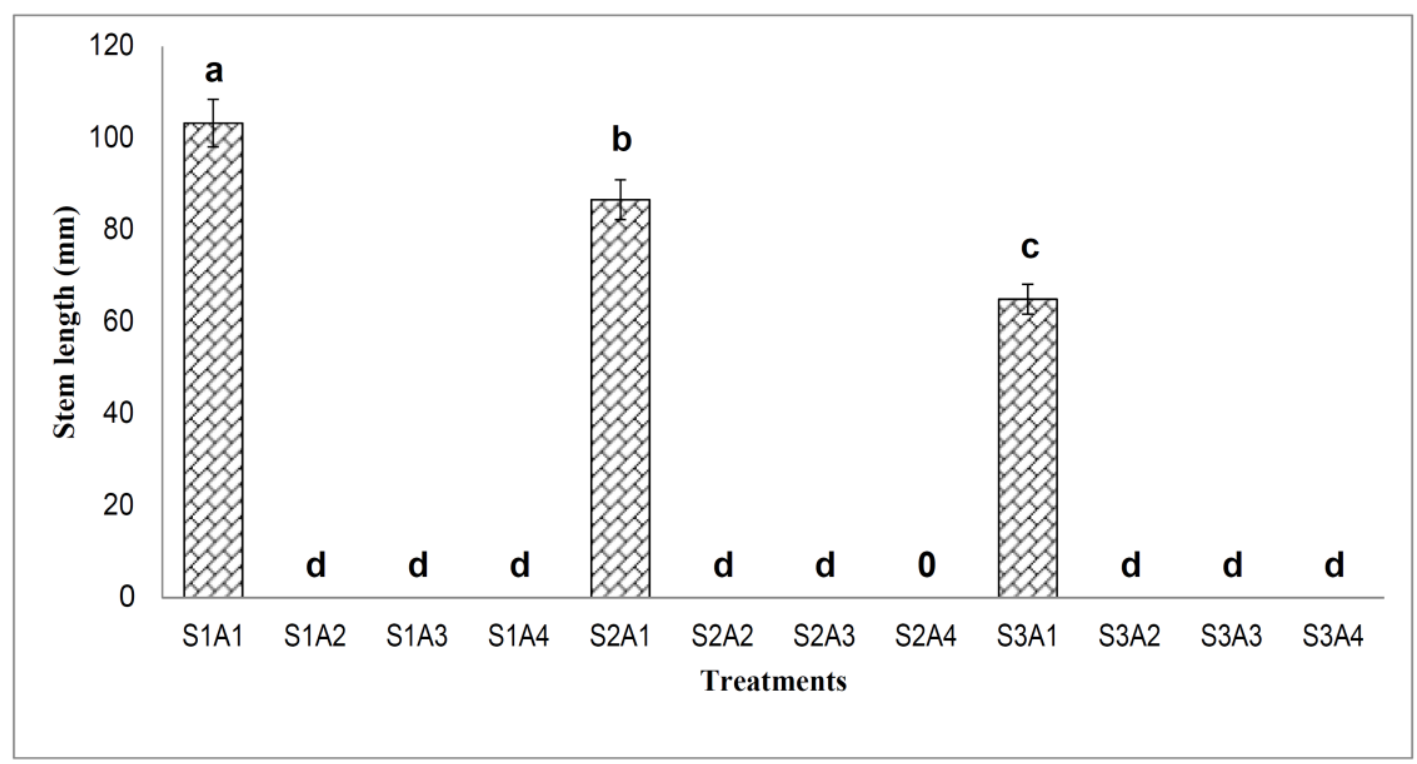

FIGURE 4. The interactive effects of salinity and drought on Lathyrus stem growth in control treatment. Different letters on the bar graphs represent a significant difference $(\mathrm{P}<0.05)$ between plant stem growth in different treatments $(\mathrm{S} 1, \mathrm{~S} 2$, and $\mathrm{S} 3$ represent EC of 0,2 , and $4 \mathrm{dS} / \mathrm{m}$, respectively, and A1, A2, A3, and A4 represent $0,0.4,0.8$, and 1.2 MPa drought stress, respectively). 


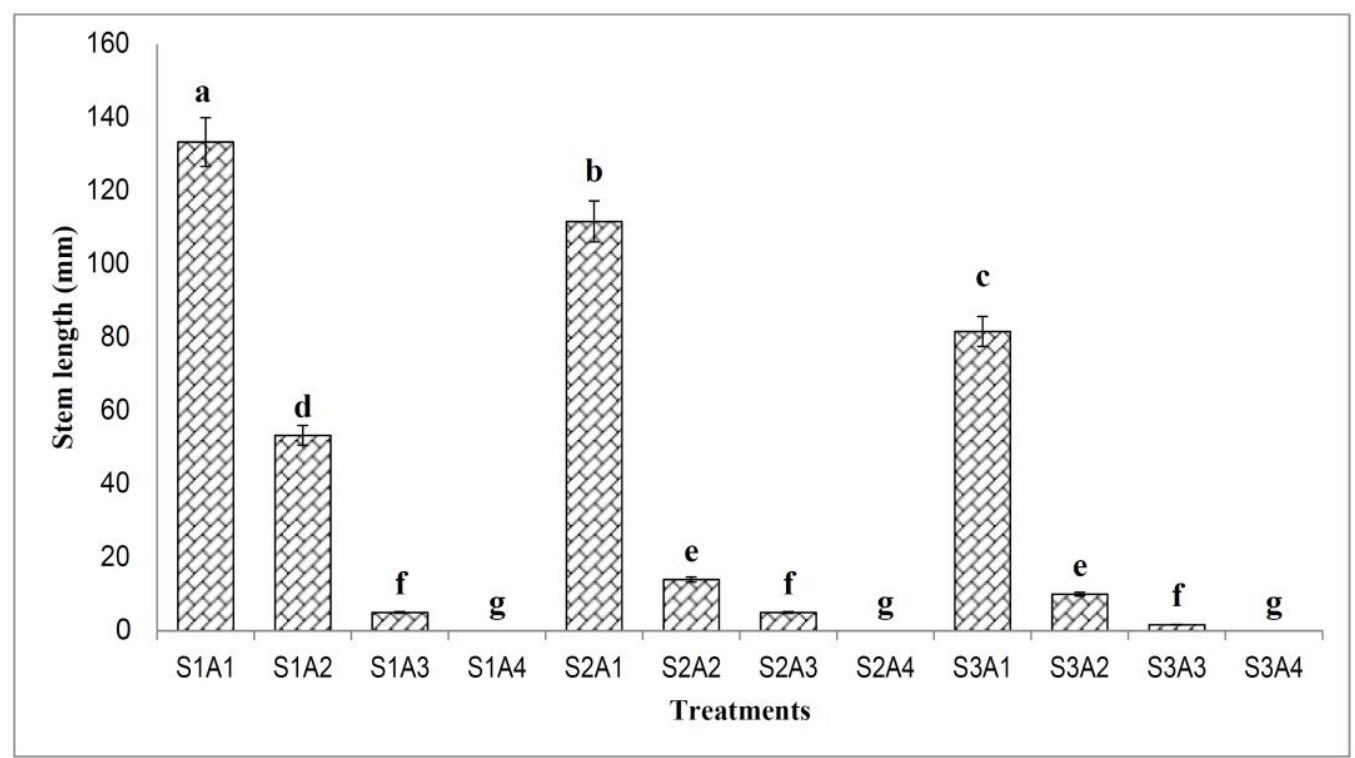

FIGURE 5. The interactive effects of salinity and drought on Lathyrus stem growth in hydropriming treatment. Different letters on the bar graphs represent a significant difference $(\mathrm{P}<0.05)$ between plant stem growth in different treatments $(\mathrm{S} 1, \mathrm{~S} 2$, and $\mathrm{S} 3$ represent EC of 0, 2, and $4 \mathrm{dS} / \mathrm{m}$, respectively, A1, A2, A3, and A4 represent 0, 0.4, 0.8, $\begin{array}{llll}\text { and } & \mathrm{MPa} & \text { drought } & \text { stress, }\end{array}$ 


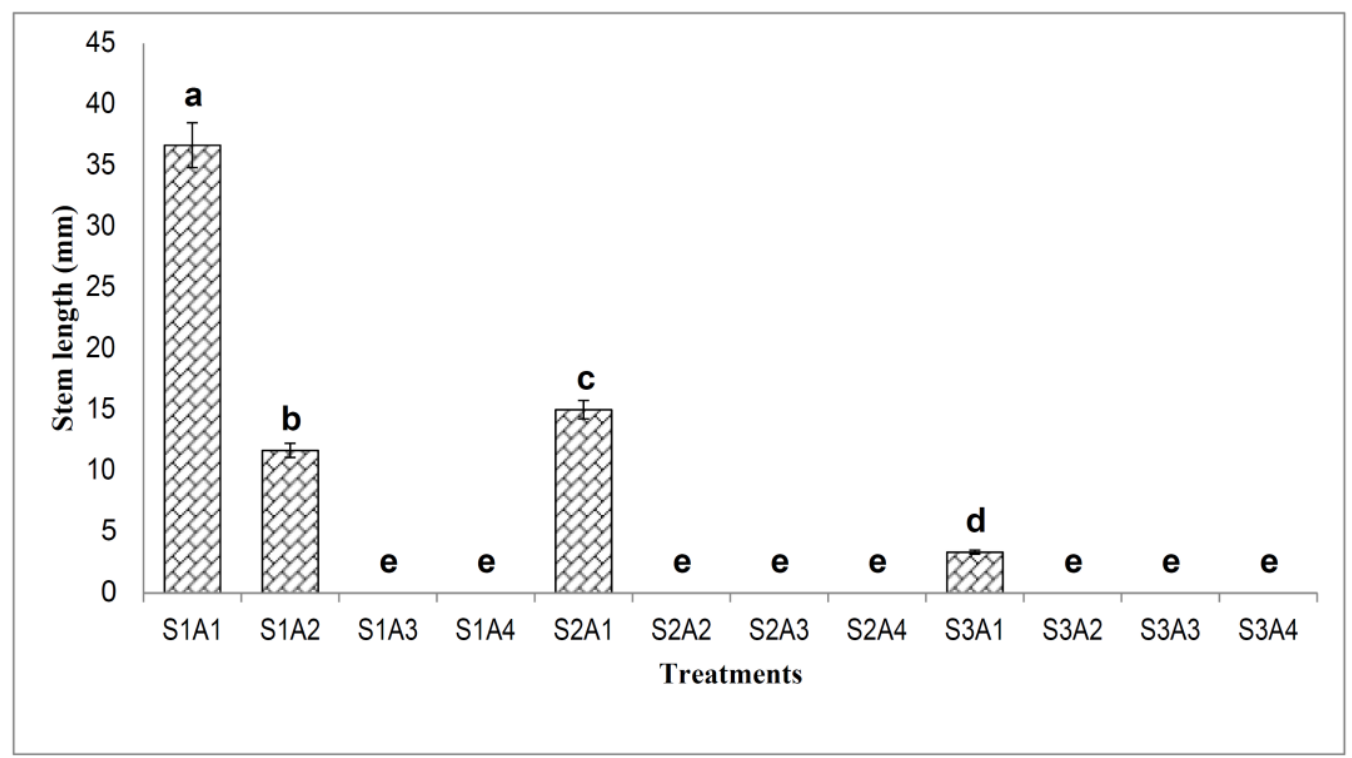

FIGURE 6. The interactive effects of salinity and drought on Lathyrus stem growth in osmopriming treatment. Different letters on the bar graphs represent a significant difference $(\mathrm{P}<0.05)$ between plant stem growth in different treatments $(\mathrm{S} 1, \mathrm{~S} 2$, and $\mathrm{S} 3$ represent EC of 0, 2, and $4 \mathrm{dS} / \mathrm{m}$, respectively, and A1, A2, A3, and A4 represent 0, 0.4, 0.8, 1.2 MPa drought stress, respectively). 